\title{
The Antioxidant Properties of Black Garlic Aqueous Extract in Vero Cell Line
}

\author{
Amna Mohamed Abdulhafith Marie*, Nastiti Wijayanti** \\ Animal Physiology Laboratory, Faculty of Biology, Universitas Gadjah Mada. \\ Jl. Teknika Selatan, Sekip Utara, Yogyakarta 55284, Indonesia. \\ Email: amnamarie@yahoo.com*; nastiti_wijayanti@ugm.ac.id**
}

\begin{abstract}
Oxidative stress has been defined as harmful because oxygen free radical attack biological molecules such as lipids, proteins and DNA. Antioxidants are substances that can prevent or slow damage to cells caused by free radicals, unstable molecules that the body produces as a reaction to environmental and other pressures. Black garlic (BG) is one of the natural resources that has been reported to have antioxidant properties. The aims of this research was to study the potential and effect of BG as antioxidant in LPS induced Vero cells. The methods of this research were used the extraction of BG by maceration method using aqueous solvents, antioxidant activity tested using DPPH assay, cytotoxicity test with WST-1 assay on 96-well plate, and NO level measurement using Griess reagent, after cells induced with LPS. The result showed that in DPPH assays BG showed ability for scavenging free radical activities. The BG aqueous extract did not show cytotoxicity on Vero cells until the concentration of $750 \mu \mathrm{g} / \mathrm{ml}$ and NO levels decreased in cells treated with a concentration of $50 \mu \mathrm{g} / \mathrm{mL}$ after LPS induction. This study concluded that the administration of aqueous extract of Black Garlic has the potential as an antioxidant.
\end{abstract}

Keywords: Black garlic extract, antioxidant, cytotoxicity, Nitric oxide, Vero cell.

\section{INTRODUCTION}

The use of herbal medicines is becoming an increasingly attractive approach for treating various inflammatory disorders. Plants of the Genus Allium are known for their production of organosulfur compounds, which process interesting biological and pharmacological properties. Among these, garlic (Allium sativum) is one of the most widely used ones. When extracted and isolated, these compounds exhibit a broad spectrum of beneficial effects against microbial infections as well as cardioprotective, anti cancerigenic, and antiinflammatory activity (Salman et al., 1999).

Black garlic (BG) is simply fresh garlic (Allium sativum L.) that has been fermented for controlled high temperature (60-90 $\square$ C) under controlled high humidity (80-90\%). Furthermore, BG does not release strong offflavor, like fresh garlic. This is because of changes to the compound allicin, which is responsible for the pungent odor, into water soluble antioxidant compounds such as S-allylcysteine, tetrahydro- $\beta$-carbolines, biologically active alkaloids, and flavonoid compounds during aging process. Enhanced bioactivity of black garlic compared with that of fresh garlic is attributed to its changes in physicochemical properties (Yuan et al., 2016). Choi et al., (2014) has declared that many valuable components within BG against diseases increased during the aging process, especially polyphenol, flavonoids, and some intermediates of Maillard reaction have been known as antioxidant agents.
S-Allylcysteine is formed by the catabolism of $\gamma$ glutamylcysteine and it inhibits oxidative damage related with aging and various diseases. Tetrahydro- $\beta$-carboline derivatives, which have been identified in BG extracts, also show antioxidant effects. Tetrahydro- $\beta$-carboline derivatives are formed by condensation between tryptophan and aldehyde, similar to the production of pyruvic acid by the allin-allicin pathway or the Maillard reaction process (Ichikawa et al., 2002

Inflammation is part of the complex biological response of body tissues to harmful stimuli, such as pathogens, damaged cells, or irritants, and is a protective response involving immune cells, blood vessels, and molecular mediators (Ferrero et al., 2007). When inflammation appears as a primary disorder can induce oxidative stress as a secondary disorder which can further enhance inflammation. On the other hand, oxidative stress as a primary disorder inflammation develops as a secondary disorder and further enhances oxidative stress- Production of reactive oxygen species (ROS) is central to progression of inflammatory disease, ROS produced by cells involved in inflammatory response (polymorphonuclear neutrophils) act as signalling molecules and inflammatory mediator. At sites of inflammation activated inflammatory cells release ROS \& RNS as well as enzymes and chemical mediators, resulting in tissue damage and oxidative stress (Biswas, 2016).

Lipopolysaccharide (LPS) interaction with a multitude of immune cells capable of producing these reactive species, can be useful or detrimental to the host. 
Macrophages, the most important producers of ROS and RNS, sense and obtain activated to eliminate bacterial infection through LPS recognition, a mechanism actually needed and advantageous to the host (Libby, 2007). However, continued exposure of high doses of LPS that trigger prolonged production of inflammatory mediators, might lead to a deleterious condition termed oxidative stress (Victor et al., 2004), due to excessive production of these radicals, associated with inflammation. Oxidative stress is a major contributing factor to the high mortality rates associated with various diseases and can sometimes potentially lead to a lethal systemic disorder, LPS toxicity induced septic shock (Aggarwal et al., 2012).

Vero cells are one of the most common mammalian continuous cell lines used in microbiology, and molecular and cell biology research. Derived from the kidney of an African green monkey (Cercopithecus aethiops) in the 1960s. Vero cells have been utilized in various activities against infectious diseases, serving as a biological material in research laboratories, a diagnostic tool in clinical laboratories, and also a cell substrate for human vaccines in pharmaceutical industries (Montagnon et al., 1998).

\section{MATERIALS AND METHOD}

The tools that were used in this research include: water bath, oven, mixer, laminar airflow (LAF), $\mathrm{CO} 2$ incubator, centrifuge, vortex, inverted microscope, microplate reader, centrifuge (Hettich) (Labgard Class II, Biological Safety Cabinet), spectrophotometer (Thermo Scientific), semi-analytical scales (Ohaus), semimicro analytic scales (AND200), shaker (Scilogex), vortex (GENIE), and rice cooker.

\section{Preparation sample}

Fresh garlic (Allium sativum L.) was purchased from a local market in Magelang, Yogyakarta, Indonesia in 2019. Whole bulbs of single clove garlics were put in the rice cooker into several layers with some sheets of absorbent paper between the layer and also the bottom of the layer The rice cooker was set on and keep warm for 14 days until they obtained the particular black colour. Black garlic peeled of and dried in the oven

$45^{\circ} \mathrm{C}$ for $24 \mathrm{~h} .150 \mathrm{~g} \mathrm{BG}$ is weighed and then blended, as much as $1500 \mathrm{ml}$ of water is added and shaken using a shaker overnight, filter using paper filter. Dry the extract using vacuum rotatory evaporator.

\section{Vero cell culture}

Vero cells were cultured in a complete culture medium in a flask. Cell culture then placed in an $\mathrm{CO}_{2}$ incubator at $37^{\circ} \mathrm{C}$ with $5 \% \mathrm{CO}_{2}$. Observations were made every day until the cell density reached $80 \%$. After confluent, cell cultures medium was discarded and then washed with
$4 \mathrm{~mL}$ PBS twice. After that, $0.05 \%$ trypsin was added as much as $1 \mathrm{~mL}$ and incubated in an incubator for 3 minutes then the release process of cell culture was observed under a microscope. Next, DMEM is added to inactivate trypsin, resuspension and transfer to a $15 \mathrm{~mL}$ conical tube, then centrifuge with $500 \mathrm{RCF}$ for 5 minutes. Discarded the supernatant and add $5 \mathrm{~mL}$ DMEM, centrifuge again. After the supernatant is removed, pellets resuspended in $1 \mathrm{~mL}$ of complete culture media. As much as $10 \mu$ suspense cells were taken and counted the number of cells with a haemocytometer under a microscope inverted. Cell density can be calculated by the formula:

Cell Density $=\underline{\text { Number of cells in box } A+B+C+D} \times 10^{4}$ cell $/ \mathrm{mL}$

$1 \times 10^{4}$ cell / $100 \mu \mathrm{l}$ culture media was seeded into each of the 96-well plates were incubated for 24 hours in a $\mathrm{CO}_{2}$ incubator to give the cell time to stick to the well.

\section{Antioxidant Activity}

\section{DPPH Radical Scavenging}

DPPH radical scavenging activity was determined according to Yokozawa et al 1998, with slight modification. In brief, $1 \mathrm{~mL}$ of $0.2 \mathrm{mM}$ DPPH radical solution prepared in ethanol was mixed with $1 \mathrm{~mL}$ of the test sample dissolved in $100 \mathrm{mM}$ Tris- $\mathrm{HCl}$ buffer $(\mathrm{pH}$ 7.4), the mixtures were then shaken up vigorously and incubate for 30 minutes at room temperature in the dark. The absorbance was measured at $517 \mathrm{~nm}$, and the radical scavenging activity was expressed as percent inhibition:

DPPH inhibition $(\%)=(1-[\mathrm{Ai}-\mathrm{Aj}] / \mathrm{Ac}) \times 100(1)$ where $\mathrm{Ai}$ is the absorbance of the mixture of $1 \mathrm{~mL}$ sample and $1 \mathrm{~mL} 0.2 \mathrm{mM} \mathrm{DPPH}, \mathrm{Aj}$ is the absorbance of the mixture of $1 \mathrm{~mL}$ sample and $1 \mathrm{~mL}$ ethanol, and Ac is the absorbance of the mixture of $1 \mathrm{~mL} 0.2 \mathrm{mM} \mathrm{DPPH}$ and $1 \mathrm{~mL}$ Tris- $\mathrm{HCl}$ buffer.

\section{Cell cytotoxicity assay}

Cell proliferation were assessed by WST-1 assay, respectively Vero cells $\left(1 \times 10^{4}\right.$ cells/well $)$ were cultured on 96-well plates containing $0.1 \mathrm{~mL}$ of culture medium for $24 \mathrm{~h}$, and then these cells were treated with different concentration of BG $(0,250,500,750,1000,1500,2000$ $\mu \mathrm{g} / \mathrm{mL}$ ) The treatment was made with 3 replications each, and then the cells were incubated in a $\mathrm{CO}_{2}$ incubator for 24 hours. Furthermore, $5 \mu \mathrm{L}$ of WST-1 reagent was added to each well and incubated for 1 hour. The absorbance was measured in a microplate reader at $450 \mathrm{~nm}$ and the percent cytotoxicity was calculated.

\section{Nitric oxide measurement (NO)}

In the cell culture supernatant, stably generated during NO reactions, were assessed to determine the amount of NO production. First, $1 \times 10^{5}$ Vero cell per well were seeded in triplicate in 6-well plates. Cells treated with LPS $(1 \mu \mathrm{g} / \mathrm{mL})$ and BG extract in different 
concentrations $(0,50,100,200 \mu \mathrm{g} / \mathrm{mL})$ for $24 \mathrm{~h}$, or untreated (control). Second, Griess reagent was prepared by mixing Griess (1) $0.1 \% \quad \mathrm{~N}$-(1-naphthyl) ethylenediamine dihydrochloride (dissolved in ddH2O) and Griess (2) $1 \%$ sulfanilamide (dissolved in $5 \%$ $\mathrm{H}_{3} \mathrm{PO}_{4}$ ) in equal volume. Lastly, $50 \mu \mathrm{L}$ of culture supernatant and $50 \mu \mathrm{L}$ of each Griess reagent were blended with micropipette and set aside for $10 \mathrm{~min}$ at room temperature, then the absorbance at $595 \mathrm{~nm}$ were measured. $\mathrm{NaNO}_{2}$ standard curve was used to calculate nitrite concentration.

\section{RESULT AND DISCUSSION}

Oxidative stress is an imbalance between free radicals and antioxidants in the body. Free radicals are oxygencontaining molecules with an uneven number of electrons. The uneven number allows them to easily react with other molecules. Free radicals can cause large chain chemical reactions in the body because they react so easily with other molecules. These reactions are called oxidation. They can be beneficial or harmful. Antioxidants are molecules that can donate an electron to a free radical without making themselves unstable.

This causes the free radical to stabilize and become less reactive (Morillas-Ruiz et al., 2006).

It is impossible to completely avoid free radical exposure and oxidative stress. However, there are things to minimize the effects of oxidative stress on the body. The main thing is to increase the levels of antioxidants and decrease on of free radicals. One method of preventing oxidative stress is to ensure that enough antioxidants in the diet. Eating five servings per day of a variety of fruits and vegetables is the best way to provide body what it needs to produce antioxidants. Black garlic is one of dietary antioxidant sources that have been reported to have antioxidant activities (Queiroz et al., 2009)

Black garlic has been developed as a functional food with antioxidant and anti-inflammatory activities. Black garlic is produced by aging fresh garlic at high temperature and high humidity (Lee et al., 2009). Throughout the aging process, polyphenol contents are increased and unstable compounds of raw garlic are converted into stable compounds such as S-allylcysteine (SAC) and S-allylmercaptocysteine (SAMC). These organosulfur compounds are also considered as synthetic $\mathrm{H}_{2} \mathrm{~S}$ donors as well as antioxidant. These compounds have been shown to be able to reduce the accumulation of ROS and appear to selectively induce nuclear factor erythroid 2-like factor (Nrf2) involved in oxidative stress defense (Shi et al., 2015). However, the antioxidant activity of BG is not directly proportional to its antiinflammatory activity. Black garlic should be considered carefully as functional foods because they produce different effects (Jeong et al., 2016).
In this study, the antioxidant properties of Black garlic were determined by the DPPH radical scavenging activity.

\section{DPPH}

DPPH showed strong absorption at $517 \mathrm{~nm}$ (purple color). DPPH radical scavenging rates of aqueous extract of black garlic-were dose dependent (Table 1). The highest DPPH radical scavenging rate was shown at $75 \%$ by the concentration of $5 \mathrm{mg} / \mathrm{ml}$. Lower than $1 \mathrm{mg} / \mathrm{ml}$ the rate of radical scavenging activity tend to give $30 \%$.

Table.1. DPPH scavenging activity result

\begin{tabular}{ccc}
\hline $\begin{array}{c}\text { Concentration } \\
(\mathbf{m g} / \mathbf{m l})\end{array}$ & $\begin{array}{c}\text { DPPH reduction } \\
\text { \% }\end{array}$ & $\begin{array}{c}\text { IC50 } \\
(\mathbf{m g} / \mathbf{m l})\end{array}$ \\
\hline 0.5 & 29.2 & 2.4 \\
1 & 30.7 & \\
3 & 69.4 & \\
5 & 75.2 & \\
\hline
\end{tabular}

As seen from Figure.1, DPPH radical scavenging abilities increased with sample concentrations. The IC50 values of $\mathrm{BG}$ for scavenging $\mathrm{DPPH}$ were $2.4 \mathrm{mg} / \mathrm{ml}$ according to their regression equations. These results were obtained in the DPPH assays and the increase in the antioxidant activities of BG may be due to the increase in total polyphenols, total flavonoids, and organosulfur compounds during aging period. The antioxidant activities of $\mathrm{BG}$ throughout the aging period were consistent with the antioxidant components measured using HPLC analysis and purification by semiprepHPLC.

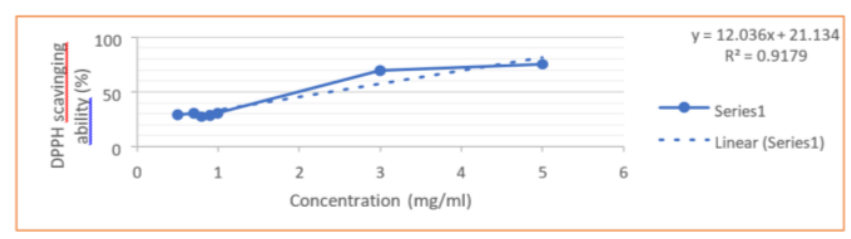

Figure 1. DPPH radical scavenging activity of black garlic extracts and individual black garlic fractions.

\section{Cytotoxicity of Black Garlic in Vero cell}

In order to determine the optimal concentrations of Black Garlic for the current study, we examined the cytotoxicity of Black Garlic aqueous extract on Vero cells by using WST-1. BG did not show cytotoxicity of Vero cells up to the concentration of $750 \mu \mathrm{g} / \mathrm{ml}$. As shown in Figure 2, BG was highly cytotoxic at concentrations $>750 \mu \mathrm{g} / \mathrm{mL}$, and its cytotoxic effect was observed regardless of the presence of LPS. In contrast, BG showed no significant cytotoxic effects on cell viability up to $2000 \mu \mathrm{g} / \mathrm{mL}$, indicating that BG was not toxic to Vero cells. 


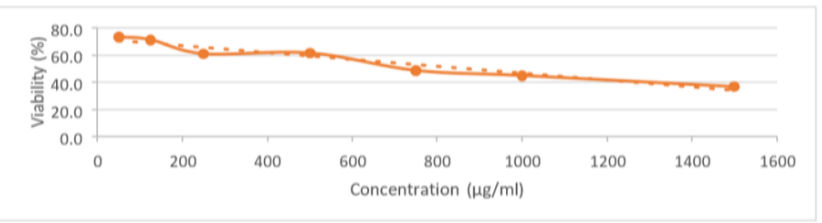

Figure 2. Effect of BG on Vero cell viability with different concentrations $(0,250,500,750,1000,1500,2000 \mu \mathrm{g} / \mathrm{mL})$ for $24 \mathrm{~h}$.

Based on the data that showed in the graph we can see that the higher the concentration of the extract given to the cell will cause a decrease Figure in cell viability and Low cell viability at high extract concentrations can be caused by the amount of organosulfur compound content found in the BG extract.

\section{Inhibitory effect of the garlic extracts on NO production in LPS-stimulated Vero cells}

Nitric oxide (NO) is a ubiquitous molecule which is formed intracellularly by L-arginine metabolism. It is a highly reactive molecule because it contains an unpaired electron in the highest orbital. For this reason NO is considered a free radical; it reacts rapidly with other molecules that contain an unpaired electron in the highest orbital, forming a stable product. Due to that it behaves as a potential antioxidant agent by virtue of its ability to reduce other molecules. In vitro experiments support this concept inasmuch as No is able to inhibit lipid peroxidation (Beckman et al., 1996).

To examine the effects of Black garlic aqueous extract on LPS-induced NO production in Vero cells, culture media were harvested, and the levels of inflammatory mediators were determined. When Vero cell were pretreated with BG, NO production decreased significantly, and the inhibitory effects of black garlic extracts were almost identical (Fig. 3).

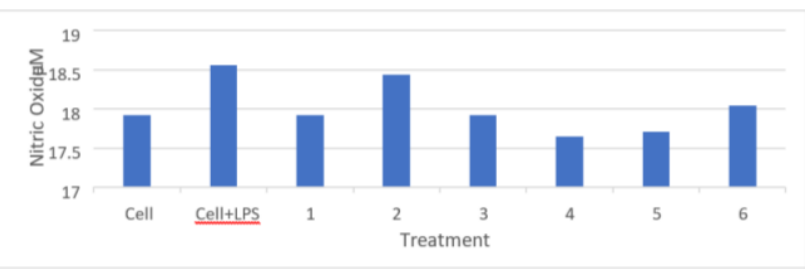

Figure 3. NO concentrations cell; cell+LPS; (1) cell+lps+Drug; (2) cell+Drug; (3) cell+LPS+BGE10 $\mu \mathrm{g} / \mathrm{ml}$; (4) cell+LPS+BGE50 $\mu \mathrm{g} / \mathrm{ml}$.; (5) celL+PS+BGE100 $\mu \mathrm{g} / \mathrm{ml}$.; (6) cell+LPS+BG200 $\mu \mathrm{g} / \mathrm{ml}$.

According to the data obtained in figure it showed the highest NO level which contain the LPS-induced negative control without $\mathrm{BG}$ extract higher than the cell control. Which is shows that black garlic aqueous extract can inhibit NO concentrations in LPS induced cells. The best concentration of BGE to inhibit NO concentration was showed by treatment 4 at $50 \mu \mathrm{g} / \mathrm{ml}$. This condition shows that $\mathrm{BG}$ with lower Concentration can be reduce the NO level more than in that in high concentration. These data indicate that BG suppressed LPS-induced NO production in Vero cells, and also its ability to suppress inflammatory mediators.

\section{CONCLUSION}

The aqueous extract of black garlic extracts have been demonstrated to show strong DPPH radical scavenging activities. The aqueous extract of black garlic did not show cytotoxicity on Vero cells until the concentration of $750 \mu \mathrm{g} / \mathrm{ml}$. Black garlic extract has potential to reduce NO level in LPS induced Vero cells at concentration $50 \mu \mathrm{g} / \mathrm{ml}$.

\section{REFERENCES}

Aggarwal, S., Dimitropoulou, C., Lu, Q., Black, S. M., \& Sharma, S. 2012. Glutathione Supplementation Attenuates Lipopolysaccharide-Induced Mitochondrial Dysfunction and Apoptosis in a Mouse Model of Acute Lung Injury. Frontiers in Physiology, 3.

Ammerman, N. C., Beier-Sexton, M., \& Azad, A. F. 2008 Growth and Maintenance of Vero Cell Lines. Current Protocols in Microbiology.

Beckman, J. S., \& Koppenol, W. H. 1996. Nitric oxide, superoxide, and peroxynitrite: the good, the bad, and ugly. American Journal of Physiology-Cell Physiology, 271(5), C1424-C1437.

Biswas, S. K. 2016. Does the Interdependence between Oxidative Stress and Inflammation Explain the Antioxidant Paradox? Oxidative Medicine and Cellular Longevity, 2016, 1-9.

Cavallito, C. J., and Bailey, J. H. 1944. Allicin, the Antibacterial Principle of Allium sativum. I. Isolation, Physical Properties and Antibacterial Action. Journal of the American Chemical Society, 66(11), 1950- 1951.

Choi, I., Cha, H., \& Lee, Y. 2014. Physicochemical and Antioxidant Properties of Black Garlic. Molecules, 19(10), 16811-16823.

Ferrero-Miliani, L., Nielsen, O. H., Andersen, P. S.,and Girardin, S. E. 2006. Chronic inflammation: importance of NOD2 and NALP3 in interleukin-1? generation. Clinical and Experimental Immunology, 147: 227-235.

Ichikawa, M., Ryu, K., Yoshida, J., Ide, N., Yoshida, S., Sasaoka, T., and Sumi, S.-I. 2002. Antioxidant effects of tetrahydro- $\beta$ carboline derivatives identified in aged garlic extract. BioFactors, 16(3-4), 57-72

Jeong, Y., Ryu, J., Shin, J.-H., Kang, M., Kang, J., Han, J., \& Kang, D. 2016. Comparison of AntiOxidant and AntiInflammatory Effects between Fresh and Aged Black Garlic Extracts. Molecules, 21(4), 430

Legg, T.J. 2017 Everything You Should Know About Oxidative Stress. Everything You Should Know About Oxidative Stress. https://www.healthline.com/health/oxidative-stress November 2019]

Libby, P. 2008. Inflammatory Mechanisms: The Molecular Basis of Inflammation and Disease. Nutrition Reviews, 65, S140 S146.

Morillas-Ruiz, J. M., \& Hernández-Sánchez, P. 2015. Oxidative Stress and Antioxidant Defenses Induced by Physical 
Exercise. Basic Principles and Clinical Significance of Oxidative Stress. doi:10.5772/61547

Morillas-Ruiz, J. M., Villegas García, J. A., López, F. J., VidalGuevara, M. L., \& Zafrilla, P. 2006.Effects of polyphenolic antioxidants on exercise-induced oxidative stress. Clinical Nutrition, 25(3), 444-453.

Montagnon, B. J.and Vincent-Falquet, J. C. 1998. Experience with the Vero cell line. Dev Biol Stand 93, 119-123

Queiroz, Y. S., Ishimoto, E. Y., Bastos, D. H. M., Sampaio, G. R., \& Torres, E. A. F. S. 2009. Garlic (Allium sativum L.) and ready-to-eat garlic products: In vitro antioxidant activity. Food Chemistry, 115(1), 371-374.

Salman, H., Bergman, M., Bessler, H., Punsky, I., \& Djaldetti, M. 1999. Effect of a garlic derivative (alliin) on peripheral blood cell immune responses. International Journal of Immunopharmacology, 21(9), 589-597.

Saryono, \& Proverawati, A. 2019. The potency of black garlic as anti-atherosclerotic: Mechanisms of action and the prospectively.

SATO, E., KOHNO, M., \& NIWANO, Y. 2006. Increased Level of Tetrahydro- $\beta$-Carboline Derivatives in Short-Term Fermented Garlic. Plant Foods for Human Nutrition, 61(4), $175-178$.
Shimoda, L. M. N., Park, C., Stokes, A. J., Gomes, H. H., \& Turner, H. (2012). Pacific Island 'Awa(Kava) Extracts, but not Isolated Kavalactones, Promote Proinflammatory Responses in Model Mast Cells. Phytotherapy Research, 26(12), 19341941.

Vanlaere, I., \& Libert, C. 2009. Matrix Metalloproteinases as Drug Targets in Infections Caused by Gram-Negative Bacteria and in Septic Shock. Clinical Microbiology Reviews, 22(2), 224-239

XU, Q., TAO, W., \& AO, Z. 2007. Antioxidant activity of vinegar melanoidins. Food Chemistry, 102(3), 841-849.

Yokozawa, T., Dong, E., Nakagawa, T., Kashiwagi, H., Nakagawa, H., Takeuchi, S., \& Chung, H. Y. 1998. In Vitro and in Vivo Studies on the Radical-Scavenging Activity of Tea. Journal of Agricultural and Food Chemistry, 46(6), 2143-2150.

Yuan, H., Sun, L., Chen, M., \& Wang, J. 2016. The Comparison of the Contents of Sugar, Amadori, and Heyns Compounds in Fresh and Black Garlic. Journal of Food Science, 81(7), C1662-C1668. 
THIS PAGE INTENTIONALLY LEFT BLANK 